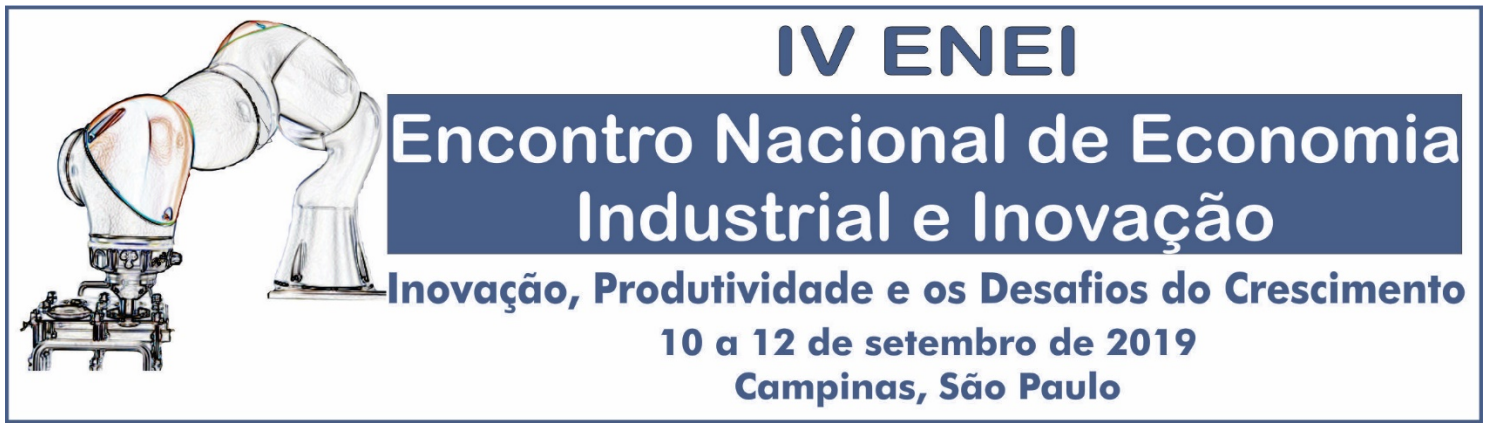

\title{
University-society collaboration in developing countries: Preliminary evidences from Brazil
}

\author{
Israel Sanches Marcellino \\ sanchesisrael@gmail.com \\ Federal University of Rio de Janeiro - UFRJ \\ Marcia Siqueira Rapini \\ Federal University of Minas Gerais - UFMG \\ msrapini@cedeplar.ufmg.br \\ Tulio Chiarini \\ National Institute of Technology - INT \\ tulio.chiarini@int.gov.br
}

\begin{abstract}
This article analyzes, in a pioneering way, the data from the Directory of Research Groups of CNPq to analyze the interaction of Brazilian universities and ICTs with society, starting with the Census 2016. The data show that universities and ICTs have a wide base of interactions, being the most expressive the interactions academic and with companies. Among the other interactions, the most important are those with government, unions and cooperatives. Regional analyses show that there are different patterns of collaboration between research groups and society and that the emphasis in interactions with firms, fostered by the Innovation Law, disregards other agents and collaborations that are especially important in some Regions.
\end{abstract}

Keywords: university collaborations, Society, Brazil, research groups

Área temática: (4) Redes e sistemas urbanos, regionais e nacionais /

(4.4) Redes de Inovação - alianças de P\&D, interações universidade-empresa, outras redes

JEL code: 
Since the 1980s universities are being "forced" to contribute to economic growth, by supporting and fostering the propensity of technology-intensive sectors to innovate, through technology transfer, interactions with companies and the creation of startups (Etzkowitz 1983; Klofsten et al. 2018). In fact, some scholars call for an "entrepreneurial" role of the universities, creating and commercializing new technologies (Bercovitz and Feldmann 2006). This role has been stimulated in several countries by policy makers and Brazil is no exception. In fact, many academic studies and public policies have proclaimed that universities in that country should follow the "entrepreneurial agenda" (Dalmarco, Hulsink, and Blois 2018).

Even if the concept of the entrepreneurial university was based on its orientation towards knowledge for the sake of solving specific challenges confronting society (Audretsch 2014), the focus on the "entrepreneurial" role of universities was mainly devoted to university-industry interactions analysis, disregarding - or putting at a secondary category at best - the interactions with other actors that form the society. Therefore, a sort of "developmental" role of universities have been defended by some scholars (Arocena, Göransson, and Sutz 2015; Brundenius, Lundvall, and Sutz 2008) since the 2000s, especially in the context of developing countries, as in Brazil where the university-industry interactions are weak due to the structural and systemic factors that do not favor the generation of innovation (Suzigan and Albuquerque 2011). In developing countries like Brazil - where companies demand little knowledge from universities - the role of universities for economic development should be based on the interaction with various social actors and not only with profit seeking companies (Arocena, Göransson, and Sutz 2015). In this context, there are scholars who suggest that not only should universities interact with actors that can pay for their knowledge but they should also be perceptible to the demands of society especially the marginalized groups (Arocena, Göransson, and Sutz 2015).

Taking into account the quarrel between the "entrepreneurial" and the "developmental" agendas of the universities within the innovation system approach in a developing country, we bring new elements through the investigation of the Brazilian case. It is interesting to call attention that the innovation system researchers do not provide homogeneous answers on the debate, especially on the role of universities. Therefore, the aim of this paper is to shed light in the broader debate about the role of universities, going beyond the university-industry relationships, showing a critical perspective on the universities" "entrepreneurial" agenda. We make empirical quantitative data analysis using the data provided by the Research Groups Directory of the Brazilian National Technological and Scientific Research Council (CNPq).

The article is organized into five sections, including this introduction and some concluding remarks. In the second section we present a brief review of the literature on the role of universities in innovation systems, focusing the Brazilian literature on that. We show that while there are ample studies on the university-industry relations, there is still a lack on the literature about the "developmental" role of the Brazilian universities, at least not in the innovation system perspective. There are however critical studies proposed mainly by "science, technology and society" scholars that bring into debate the fragilities of giving more attention to university-industry relations in detriment to the other actors (Dagnino 2015) - and by "educational studies" (Silveira and Bianchetti 2016)

In section three we present the methodology used to construct our database. The data was sourced from The National Council for Scientific and Technological Development (CNPq), which is responsible for gathering information about the research groups (Grupos de Pesquisa). We focus our analysis on 2014 and 2016, which are the two last Census years available. The database was classified in other to identify the research groups' partner, looking beyond the university-industry relations. In section four we present exploratory analysis focusing on knowledge field differences, national and regional levels disparities and on the top 5 most interactive groups per geographical region. In section five we conclude the article, reflecting on recent ST\&I policy and its impact on the role of universities in developing countries. 
There are at least three authors to whom the formation of a traditional "canonic" innovation systems approach can be attributed. The seminal contributions of these authors were made through the analysis of cases of national innovation systems (NIS) of developed countries: Freeman (1987, 1995), who analyzed the Japanese case and emphasized the historical dimension; Nelson (1993), who analyzed the case of the United States and focused on the role of explicit policy and scientifictechnological institutions and Lundvall (1992), who analyzed the case of the Scandinavian countries and highlighted the role of interactions, mainly between producers and users.

The university, within this traditional vision, plays a secondary role in the face of explicit public policies and the relationships established between producers, suppliers and users. Basically, the overview of the mainstream literature on innovation systems shows that the main contribution of universities in innovation systems is to serve as sources of knowledge and to provide competences through the training of professionals. A common denominator between these visions is the fact that they have observed the reality of developed countries. Of course, this characteristic does not take away the validity of the conclusions reached, but it generates notions of limited adaptability to the context of developing countries. The issue of the role of universities is also influenced by this bias (Klevorick et al. 1995; Nelson and Rosenberg 1993; Freeman 1994; Lundvall 2002, 2007).

Aiming to build a vision more suited to the specificities of the context of developing countries, a strand of NIS literature proposed by Latin American scholars emerged. They adapted the concept of NIS to the specificities of developing countries' realities, broadening the theoreticalconceptual basis, including new analytical dimensions. As examples of contributions of this aspect of the literature, we can highlight the importance of considering the industrialization process and the role of demand (Arocena and Sutz 2005), the importance of aspects related to the country's international insertion (Cassiolato and Lastres 2008) and the role of implicit public policies (Coutinho 2005).

On the role of universities in innovation systems in Latin America, in general, we can identify two major currents of thought. One is based on the economic, historical and institutional specificities of both the innovation system and the universities themselves and their role in the innovation system (Arocena and Sutz 2005, 2011, 2013). In another, the theme of the role of the universities in innovation systems is thought of by adapting analytical models of the universityindustry interaction type (Dutrénit and Arza 2010; Dutrénit and Núñez 2017; Suzigan, Albuquerque, and Cario 2011) and the triple helix type (Mello, Fuentes, and Iacobucci 2016).

The first group of contributions identified in the literature relies on the pioneering spirit of Uruguayan researchers, which have been influencing researchers from other countries in the region, such as Cuba (Núñez and Quiñones 2016) and Brazil (Suzigan and Albuquerque 2011). By placing the historical-institutional perspective at the core, these scholars highlight the role of regional specificities as elements that condition the disjointed aspect of the national innovation systems of countries such as Brazil and the pattern of "disconnected universities" (Arocena and Sutz 2005).

The second group of scholars, which is more diffuse and covers a more plural range of views on the concept of innovation systems, brings together those who seek a more aligned vision to Latin American specificities and those who adhere to what is called the "narrow perspective" of innovation systems (Cassiolato and Lastres 2008).

In Brazil, the availability of data makes it possible to carry out studies with ample empirical evidence of patterns of universities-industry interactions with different perspectives: national (Rapini et al. 2019; Suzigan et al. 2009; A C Fernandes et al. 2010), sectoral (Britto et al. 2012; Ferreira and Ramos 2015; Paranhos and Perin 2018; Ana Cristina Fernandes and Lima 2018; Conceição Fátima Silva and Suzigan 2018), regional (Oliveira et al. 2018), regionalized sectoral (Tatsch, Ruffoni, and Botellho 2016; Ruffoni and Rosa 2018), higher education institutions (Closs et al. 2012; Reynolds and Negri 2019), fields of knowledge (Britto et al. 2012; Garcia et al. 2014; Caliari and Chiarini 2018) and cases of companies (Gielfi et al. 2017; Dias et al. 2018). Studies in 
this area often point to the scarcity of interactions between universities and companies as an element that influences the low dynamism of the NIS in Brazil.

The previous diagnosis in Brazil persists despite decades of public policies to support this type of interaction (Rapini et al. 2019), assuming a paradoxical tone and generating apparent perplexity in the regulatory debate. The few successful cases, on the other hand, usually end up being associated with the formation of "islands" of interaction, the causes of which are associated with historical determinants, long-term policies and with patient processes of capability building (Suzigan and Albuquerque 2011). There are studies that show that interactions with companies are less complex and focus on the routine production of the company (such as testing and assistance in quality control) (Suzigan and Albuquerque 2011; A C Fernandes et al. 2010); however, since 2003 innovative firms have cooperated relatively more with universities and research institutes (Rapini et al. 2019).

By advancing research on the subject from a holistic approach, the literature that investigates the role of universities in Latin America from a historical-institutional perspective focuses on a "broad conception" of innovation systems. Consequently, these analyses seek to affirm themselves more in theoretical elements and less in empirical evidence from field studies or secondary data. Therefore, despite providing useful elements to explain the gaps in the understanding of the university-industry interaction type literature, the historical-institutional view lacks evidences organized and presented in a systematic manner, through primary and secondary data, that could reinforce its conclusions. This scarcity is mainly felt in relation to the interactions between universities and other actors of the innovation system other than profit seeking companies, such as trade unions, foundations, hospitals etc.

On the other hand, by taking as a theoretical-methodological starting point the replication of analytical models from developed countries, the literature that is based on case studies and secondary data analysis tends to adhere to a "narrow approach" of innovation systems. As a consequence, those analyses usually emphasize the direct links between educational and research institutions and profit seeking companies, including, at most, the government.

These issues constitute gaps in the literature on the role of universities in innovation systems in Latin America in general, and in Brazil in particular. While there are considerable studies considering university-industry relations, there are just a few considering a broad perspective of possible relations among universities and other actors. For instance, Tatsch, Ruffoni, and Botellho (2016) - using the same data source we use here - analyzed interactions among health field research groups and other possible actors (according to the Directory of Research Groups) located in a specific region of Brazil. They did not focus on university-industry relations; rather they focus in an ample analysis of university relationships and found that most of them interact with hospitals, other universities and a various types and sizes of productive sector organizations.

\section{$3 \quad$ Methodology}

The National Council for Scientific and Technological Development (CNPq) is a fifty yearold organization of the Brazilian Ministry of Science, Technology, Innovations and Communications (Ministério da Ciência, Tecnologia, Inovações e Comunicações - MCTIC) responsible for distributing research grants to the Brazilian scientific and technological communities. CNPq developed in the 1990s a Directory of Research Groups (Diretório dos Grupos de Pesquisa) which is a database that collects biennially information about research activities in Brazil using the "research group" as the unity of analysis. The directory provides a proxy for studying research activities in the country and, since 2002, interactions with distinct actors from the Brazilian Innovation System were introduced in the questionnaire to be answered by leaders' groups. Although there are intrinsic limitations to information collection, the database supplies evidences not only from university-industry interactions in the country but also from universitysociety interactions. Among other information, the records detail, by interaction link: 

a) the name of the research group;
b) the institution to which the group is linked;
c) the municipality where the group is located;
d) the area of knowledge to which the group is dedicated;
e) the name of the partner organization and;
f) the type of relationship established.

The previous information is particularly useful because they shed light on the dimension not explored by the literature that analyzes the interactions between universities and profit-seeking companies. Observing these data, we intended to perform descriptive analysis that characterizes the interactions between universities and distinct actors of the Brazilian innovation system. To this end, in the next section, descriptive statistics and indicators will be calculated that reflect the types of partners and the modes of interaction informed by leaders of research groups in Brazilian universities.

The Directory of Research Groups proposes 14 types of possible relations between research groups and distinct actors ${ }^{1}$. Each leader can list at most three types of relationship that are more frequent. University research groups relations with external actors can be classified in nine different types and the inverse, that is, relations from external research groups with university research groups can be of four kinds.

We present in Table 1 a list of possible relationships between groups and external actors, and the ones with asterisks indicate that bilateral relationships are possible. The mode of interaction indicated by number 4, i.e., "supply of inputs and materials not linked to joint projects" was excluded in the subsequent analyses as it does not comprise collaborative relationships.

Table 1 - Modes of Interaction between Research Groups and distinct external actors

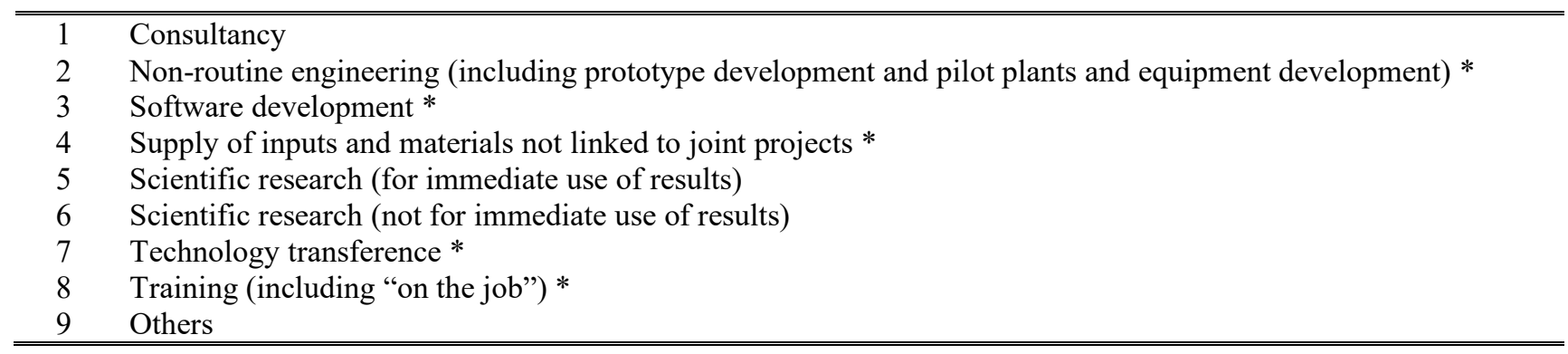

Source: CNPq (Directory of Research Groups). Note: $(*)$ bilateral relationships are possible.

The first census database was recorded in 1993 and it embraced 99 institutions throughout the country, 4,402 research groups and over 21 thousand researchers. Since then, the numbers of institutions, research groups and researchers have been increasing and the last census, which was made in 2016, comprised 531 institutions, more than 37 thousand research groups and almost 200 thousand researches (Table 2).

For the present article, we used data available at the Directory for 2014 and 2016. Therefore, we can see from Table 2 that in 2014 there were over 35 thousand groups of which 9.3 thousand had any type of interaction with external agents, while in 2016 both total groups and the interactive ones have increase. It is interesting to note too that both researchers and $\mathrm{PhD}$ researchers have increased from 2014 to 2016.

\footnotetext{
1 The Directory of Research Groups from CNPq has a not neglectable limitation: the 14 types of relations do not provide any sort of intensity scale, therefore comparisons with other key studies (Klevorick et al. 1995; Cohen, Nelson, and Walsh 2002; Meyer-Krahmer and Schmoch 1998) are not possible.
} 
Table 2 - Number of institutions, research groups, researches and PhD researchers, Brazil, 2000-2016

\begin{tabular}{lrrrrrrrr}
\hline \hline & \multicolumn{1}{c}{2000} & \multicolumn{1}{c}{2002} & \multicolumn{1}{c}{2004} & \multicolumn{2}{c}{2006} & 2008 & 2010 & 2014 \\
\hline Total institutions & 224 & 268 & 375 & 403 & 422 & 452 & 492 & 531 \\
Total groups & 11,76 & 15,158 & 19,47 & 21,024 & 22,797 & 27,523 & 35,424 & 37,640 \\
Interactive groups & - & 1,249 & 2,151 & 2,509 & 2,726 & 3,506 & 9,348 & 12,681 \\
Researchers (R) & 48,781 & 56,891 & 77,649 & 90,32 & 104,018 & 128,892 & 180,262 & 199,566 \\
PhD researchers (D) & 27,662 & 33,947 & 47,973 & 57,586 & 66,785 & 81,726 & 116,427 & 130,140 \\
$(\mathrm{D}) /(\mathrm{R})$ in \% & 56.7 & 59.7 & 61.8 & 63.8 & 64.2 & 63.4 & 64.6 & 65.2 \\
\hline \hline
\end{tabular}

Source: Authors' own. Data sourced from CNPq (Directory of Research Groups).

In order to analyze the interactions of universities with society, the Directory provides 15 different categories as shown in Table 3. However, for analytical simplicity, we grouped them and created new ones, namely: government (1), universities $(2+5)$, trade unions $(3+15)$, companies $(6+7+10)$, cooperatives $(4)$, hospitals $(12+13)$ and others $(8+9+11+14)$.

The data were selected in order to investigate how many agents in each category interact with the research groups. In doing so, we counted how many different National Registry of Legal Entities (Cadastro Nacional de Pessoa Jurídica - CNPJ) existed in each category. In addition, we also analyzed how many relationships each category had with the research groups. Possible relationships (research groups $->$ society and society $->$ research groups) are listed in Table 4 and Table 5. Research groups can declare up to three types of relationships, whose flow go from the research group to the society and vice-versa. Thus, the relationships of each group were added to reach the total number.

Table 3 - Categories of each actor, according to the Directory of Research Groups

\begin{tabular}{cl|cl}
\hline \hline Category & \multicolumn{1}{c|}{ Type of institution } & Category & \multicolumn{1}{c}{ Type of institution } \\
\hline 1 & Government & 9 & Foreign institutions \\
2 & Domestic universities* & 10 & Domestic public companies \\
3 & Domestic associations** & 11 & Foundations \\
4 & Domestic cooperatives & 12 & Domestic hospitals \\
5 & Foreing universities* & 13 & Foreign hospitals \\
6 & Domestic companies & 14 & Foreing governments \\
7 & Multinational companies & 15 & Foreing associations \\
8 & Banks & - & \\
\hline \hline
\end{tabular}

Source: Authors' own. Note: $(*)$ In this category we included also colleges and research institutes; $(* *)$ in this category we included also trade unions and the S-System (i.e., a joint system of social contributions paid by companies: National Service of Rural Apprenticeship - SENAR; National Service of Trade Apprenticeship - SENAC; National Trade Social Service - SESC; National Service of Cooperativism Apprenticeship - SESCOOP; National Service of Industrial Apprenticeship - SENAI; Industry Social Service - SESI; Social Service of Transportation - SEST; National Service of Transportation Apprenticeship - SENAT; and Brazilian Service of Micro and Small Size Companies Support - SEBRAE).

Table 4 - Modes of interactions between research groups and society

\footnotetext{
Scientific research with immediate application of results

Scientific research without immediate application of results

Material inputs supply for the activities of the partner not linked to a specific project of mutual interest

Non-routine engineering activities including the development of prototypes or pilot plants for the partner

Software development for the partner

Technology transfer to the partner

Technical consultancy activities not included in any of the previous categories

Training partner's staff, including courses and training on the job

Other predominant types of relationships that do not fit into any of the above
} 
Material inputs supply for the activities of the partner not linked to a specific project of mutual interest

Non-routine engineering activities including the development of prototypes or pilot plants for the research group

Software development for the research group

Technology transfer to the research group

Training research group's staff, including courses and training on the job

Source: Authors' own. Data sourced from CNPq (Directory of Research Groups), 2016.

Finally we would like to mention that our database has important limitations. Firstly, adherence to the Directory is voluntary and spontaneous, although researchers are highly encouraged to participate, mainly because the updated information is a precondition for access to public funding and scientific research. It should be emphasized that the interaction with the productive sector is not a criterion used by the development agencies to evaluate the performance of the research, which may explain their expressive underestimation. Finally, the questionnaire was designed to capture university-industry interactions; therefore, interactions with other agents may not be well captured.

\section{$4 \quad$ Exploratory data analysis}

\subsection{Knowledge field differences}

By 2014, over 35 thousand research groups were enrolled in the Directory of Research Groups and in 2016, they were over 37 thousand (Table 2). It is interesting to note that the number of interacting groups in 2014 was 9,348 (26.4\%) and in 2016 it was 12.681 (33.7\%) (Table 2), as presented previously. Notwithstanding that, we can acknowledge there are appreciable contrasts among those groups if we classify them by their knowledge field.

We show in Table 6 the number groups and the share of interactive ones by knowledge field. There are noticeable differences among knowledge fields in what regards the interaction among universities and other agents. Therefore, if we consider the different dynamics of distinct knowledge fields - in what regards its creation, diffusion and use - we can realize that universities' interactions differ. In fact, Garcia et al. (2014), using the data from the 2004 Directory of Research Groups edition, showed that "Engineering" and "Agricultural Sciences" research groups in Brazil interact more if compared to others.

Table 6 - Groups by knowledge field, 2014 and 2016

\begin{tabular}{|c|c|c|c|c|c|c|}
\hline \multirow[b]{2}{*}{ Knowledge field } & \multicolumn{3}{|c|}{2014} & \multicolumn{3}{|c|}{2016} \\
\hline & $\begin{array}{c}\text { Total } \\
\text { groups } \\
\text { (a) }\end{array}$ & $\begin{array}{l}\text { Interactive } \\
\text { groups } \\
\text { (b) }\end{array}$ & $\begin{array}{c}(\mathrm{b}) /(\mathrm{a}) \\
(\%)\end{array}$ & $\begin{array}{l}\text { Total } \\
\text { groups } \\
\text { (a) }\end{array}$ & $\begin{array}{l}\text { Interactive } \\
\text { groups } \\
\text { (b) }\end{array}$ & $\begin{array}{c}(\mathrm{b}) /(\mathrm{a}) \\
(\%)\end{array}$ \\
\hline Human Sciences & 7,408 & 1,251 & 16.9 & 8,091 & 2,028 & 25.1 \\
\hline Social Sciences & 4,841 & 943 & 19.5 & 5,363 & 1,360 & 25.4 \\
\hline Health Sciences & 5,609 & 1,461 & 26.1 & 5,877 & 2,045 & 34.8 \\
\hline Engineering & 4,676 & 1,747 & 37.4 & 4,970 & 2,049 & 41.2 \\
\hline Biological Science & 3,650 & 1,350 & 37.0 & 3,668 & 1,721 & 46.9 \\
\hline Agricultural Science & 3,292 & 1,241 & 37.7 & 3,355 & 1,562 & 46.6 \\
\hline Earth and Exact Science & 3,494 & 990 & 28.3 & 3,631 & 1,339 & 36.9 \\
\hline Linguistic and arts & 2,454 & 365 & 14.9 & 2,655 & 575 & 21.5 \\
\hline Other fields & - & - & - & 30 & 5 & 16.7 \\
\hline Total & 35,424 & 9,348 & 26.4 & 37,640 & 12,681 & 33.7 \\
\hline
\end{tabular}

Source: Authors' own. Data sourced from CNPq (Directory of Research Groups), 2014 and 2016.

Using the database we constructed for this paper, we can see that, despite the existence of a relevant concentration of research groups in "Human Sciences" and "Social Sciences" (34.6\% in 
2014 and $35.7 \%$ in 2016), most interactive groups belong to "Engineering" (18.7\% and 16.2\%), "Health Sciences" (15.6\% and 16.1\%) and "Biological Sciences" (14.4\% and 13.6\%).

In a complementary analysis it is possible to verify the "interactive groups/total groups" ratio, that is, the share of interactive groups in total groups according to knowledge field. As a consequence, "Agricultural Sciences" (37.7\% in 2014 and $46.6 \%$ in 2016) and "Engineering" (37.4\% and $41.2 \%$ ) can be highlighted (Table 6).

\subsection{University-society interactions by agent typology}

In Table 7 we show the number of agents by category - government, universities, trade unions, cooperatives, profit seeking companies, hospitals and others - with whom thousands of research groups interacted in 2014 and 2016 and we also present the number of existing relationships. In addition, we show the ratio numbers of relationships per agent.

A first analysis from Table 7 shows that universities are interacting more and more with agents outside their walls and the number of relations has expanded significantly from about 30 thousand to roughly 45 thousand. In both 2014 and 2016, universities in Brazil have interacted not only with profit seeking companies but also with other agents in the society. From a total of 5.9 thousand agents in 2016, almost 50\% are profit seeking companies and $20 \%$ are other universities. The rest ranges from government to hospitals. Consequently, universities' relations with external world are neither restricted to university-industry relations nor to university-industry-government relations (triple helix). In fact, most of universities' relations are not with profit seeking companies ( 8.5 thousand over a total of 45 thousand). In other words, while the largest number of agents with whom universities interact was profit seeking companies, the largest number of interactions was performed with other universities (Table 7), jeopardizing the current emphasis on the universities' "entrepreneurial" agenda.

Indeed, we observe that the number of profit seeking companies with whom universities have interacted has decreased from 2014 to 2015 in Brazil in absolute terms. The same can be said about the number of interactions, that is, one can observe a slight drop in the number of interactions among them. However, we perceive an expansion in the number of universities interacting with other universities and also a considerable rise in number of interactions among them, from over 16 thousand relations in 2014 to more than 30 thousand in 2016.

Table 7 - Types of agents and interactions in Brazil, 2014 and 2016

\begin{tabular}{|c|c|c|c|c|c|c|c|c|c|c|}
\hline & \multicolumn{5}{|c|}{2014} & \multicolumn{5}{|c|}{2016} \\
\hline & \multicolumn{2}{|c|}{$\begin{array}{l}\text { Agents } \\
\text { (a) }\end{array}$} & \multicolumn{2}{|c|}{$\begin{array}{l}\text { Interactions } \\
\text { (b) }\end{array}$} & \multirow{2}{*}{$\begin{array}{c}(\mathrm{a}) /(\mathrm{b}) \\
\mathrm{N} .\end{array}$} & \multicolumn{2}{|c|}{$\begin{array}{l}\text { Agents } \\
\text { (a) }\end{array}$} & \multicolumn{2}{|c|}{$\begin{array}{l}\text { Interactions } \\
\text { (b) }\end{array}$} & \multirow{2}{*}{$\frac{(\mathrm{a}) /(\mathrm{b})}{\mathrm{N} .}$} \\
\hline & N. & $\%$ & $\mathrm{~N}$ & $\%$ & & N. & $\%$ & $\mathrm{~N}$ & $\%$ & \\
\hline Government & 373 & 6.5 & 1,834 & 6.0 & 4.9 & 415 & 7.0 & 2,164 & 4.7 & 5.2 \\
\hline Universities & 1,059 & 18.4 & 16,282 & 53.6 & 15.4 & 1,327 & 22.3 & 30,208 & 66.2 & 22.8 \\
\hline Trade Unions & 700 & 12.1 & 1,482 & 4.9 & 2.1 & 746 & 12.5 & 1,916 & 4.2 & 2.6 \\
\hline Cooperatives & 95 & 1.6 & 262 & 0.9 & 2.8 & 96 & 1.6 & 269 & 0.6 & 2.8 \\
\hline Companies & 3,120 & 54.1 & 8,650 & 28.5 & 2.8 & 2,946 & 49.4 & 8,558 & 18.7 & 2.9 \\
\hline Hospital & 108 & 1.9 & 390 & 1.3 & 3.6 & 111 & 1.9 & 459 & 1.0 & 4.1 \\
\hline Others & 311 & 5.4 & 1,462 & 4.8 & 4.7 & 321 & 5.4 & 2,089 & 4.6 & 6.5 \\
\hline Total & 5,766 & 100 & 30,362 & 100 & 5.3 & 5,962 & 100 & 45,663 & 100 & 7.7 \\
\hline
\end{tabular}

Source: Authors' own. Data sourced from CNPq (Directory of Research Groups), 2014 and 2016.

The highest relationships per agent occur when institutions are other universities. This is expected since most relationships are related to research activities and research groups are more likely to conduct this kind of activities in cooperation with other research groups from other universities or research institutes rather than with other agents. The ratio relationships/agent in general has increased from 5.3 to 7.7 in the period; however, the ratio for university-university 
relations has increased from 15.4 to 22.8 in the same period while the ratio for university-industry has a discreet raise from 2.8 to 2.9 .

Can the previous data assure that universities in Brazil are no longer ivory towers disconnected to the real world? Can we assure that universities are less focused exclusively on knowledge for their own sake? What we assure is that Brazilian universities are more connected to other agents than ever before, permitting therefore a flow of knowledge that once was restricted within their walls. However, most of interactions happens among universities, so if the knowledge is flowing from one university, its direction is mainly to another university, that is, within the academic realms.

\subsection{Regional analysis}

As presented in many studies, the S\&T dynamics in Brazil differ regionally and intellectual and research assets are concentrated in the South and Southeast region of the country (Santos and Caliari 2012; Chiarini et al. 2014; Albuquerque et al. 2002; Sidone, Haddad, and Mena-Chalco 2016), mainly in four states: São Paulo, Minas Gerais, Rio de Janeiro and Rio Grande do Sul (Chiarini et al. 2014). Therefore, one can expect that university-society relations may alter accordingly.

In fact, when observing data presented in Table 8 , we can notice that the Southeast and South regions concentrate $66.3 \%$ of total groups in 2014 and $65.5 \%$ in 2016 . They also concentrate most of the interactive research groups $(67.5 \%$ and $65.9 \%$, in 2014 and 2016 respectively). These findings are expected once those regions concentrate most universities and research institutes, despite public efforts to reduce such concentration, consequently the Brazilian Innovation System is characterized by strong regional concentration and limited spatial penetration (Diniz and Vieira 2015).

Table 8 - Groups by geographical region, 2014 and 2016

\begin{tabular}{lccc|rrr}
\hline \hline & \multicolumn{3}{c|}{ Census 2014 } & \multicolumn{3}{c}{ Census 2016 } \\
\cline { 2 - 7 } Region & $\begin{array}{c}\text { Total groups } \\
\text { (a) }\end{array}$ & $\begin{array}{c}\text { Interactive } \\
\text { groups } \\
\text { (b) }\end{array}$ & $\begin{array}{c}\text { (b)/(a) } \\
(\%)\end{array}$ & $\begin{array}{c}\text { Total groups } \\
\text { (a) }\end{array}$ & $\begin{array}{c}\text { Interactive } \\
\text { groups } \\
(\mathrm{b})\end{array}$ & $\begin{array}{c}(\mathrm{b}) /(\mathrm{a}) \\
(\%)\end{array}$ \\
\hline Southeast & 15,549 & 4,203 & 27.0 & 16,009 & 5,509 & 34.4 \\
South & 7,938 & 2,111 & 26.6 & 8,637 & 2,851 & 33.6 \\
Central-West & 2,654 & 739 & 27.8 & 2,899 & 1,070 & 36.9 \\
North & 2,068 & 503 & 24.3 & 2,382 & 760 & 31.9 \\
Northeast & 7,215 & 1,792 & 24.8 & 7,713 & 2,491 & 32.3 \\
\hline Total & 35,424 & 9,348 & 26.4 & 37,640 & 12,681 & 33.7 \\
\hline \hline
\end{tabular}

Source: Authors' own. Data sourced from CNPq (Directory of Research Groups), 2014 and 2016.

\subsubsection{Southeast and South regions}

When considering the Southeast and South regions we can notice that for both regions, universities have interacted the most with profit seeking firms. For the former region, universities interacted with 1,713 companies (representing $41.7 \%$ of total agents with whom universities have interacted) while for the latter, universities interacted with 1,037 profit seeking companies (41.1\% of total agents). However, when considering the interactions intensity, university-university relations are the most intense for both regions $(68.0 \%$ and $61.7 \%$ for the Southeast and South regions, respectively) (Table 9). These two regions reflect the same pattern observed for Brazil as a whole, as presented previously.

It is noteworthy that in the South regions, university-trade union and universitycooperatives relations are more intense than in the Southeast. For the first case, universities interacted with 219 trade unions (from the South or any other region in Brazil) and the intensity of 
their relations represented $5.0 \%$ of total, while for the second, they interacted with 55 cooperatives (from the South or any other region) and the intensity if they relations represented $1.3 \%$ of total.

Table 9 - Types of agents and interactions in Southeast and South regions, 2016

\begin{tabular}{|c|c|c|c|c|c|c|c|c|}
\hline & \multicolumn{4}{|c|}{ Southeast } & \multicolumn{4}{|c|}{ South } \\
\hline & Agents & $\%$ & Interactions & $\%$ & Agents & $\%$ & Interactions & $\%$ \\
\hline Government & 234 & 5.7 & 867 & 4.0 & 144 & 5.7 & 483 & 4.4 \\
\hline Universities & 1,529 & 37.2 & 14,680 & 68.0 & 920 & 36.5 & 6,776 & 61.7 \\
\hline Trade Unions & 351 & 8.5 & 705 & 3.3 & 219 & 8.7 & 547 & 5.0 \\
\hline Cooperatives & 16 & 0.4 & 41 & 0.2 & 55 & 2.2 & 144 & 1.3 \\
\hline Companies & 1,713 & 41.7 & 4,065 & 18.8 & 1,037 & 41.1 & 2,455 & 22.3 \\
\hline Hospital & 58 & 1.4 & 218 & 1.0 & 38 & 1.5 & 113 & 1.0 \\
\hline Others & 208 & 5.1 & 1025 & 4.7 & 110 & 4.4 & 468 & 4.3 \\
\hline Total & 4,109 & 100 & 21,601 & 100 & 2,523 & 100 & 10,986 & 100 \\
\hline
\end{tabular}

Source: Authors' own. Data sourced from CNPq (Directory of Research Groups), 2016. Note: there is double counting once one research group could have interacted with agents from other regions too.

\subsubsection{The other regions}

The other geographical regions of Brazil, that is, Central-West, Northeast and North, concentrate less research groups vis-à-vis the other two regions, however, this does not mean the universities located there are relatively less interactive. In fact, what we can observe from Table 8 is that for 2016, the interactive groups/groups ratio was higher for the Central-West region.

Another interesting finding that can be highlighted is the fact that in university relations with external agents in Central-West, North and Northeast Regions, profit seeking companies are not the main ones. Indeed, they represent, respectively, $21.1 \% ; 26.8 \%$ and $20.8 \%$ of total partners in 2016 . For these regions, university-university relations are more intense than in the Southeast and South regions and they represent $72.1 \%, 68.7 \%$ and $69.1 \%$ of total interactions in Central-West, Northeast and North respectively, while for the Southeast and the South regions, they represented $68.0 \%$ and $61.7 \%$, accordingly.

Table 10 - Types of Agents and interactions in Central-West, Northeast and North Regions of Brazil, 2016

\begin{tabular}{|c|c|c|c|c|c|c|c|c|c|c|c|c|}
\hline & \multicolumn{4}{|c|}{ Central-West } & \multicolumn{4}{|c|}{ Northeast } & \multicolumn{4}{|c|}{ North } \\
\hline & Agents & $\%$ & Interactions & $\%$ & Agents & $\%$ & Interactions & $\%$ & Agents & $\%$ & Interactions & $\%$ \\
\hline Government & 77 & 7.9 & 228 & 6.2 & 163 & 7.5 & 474 & 5.5 & 63 & 8.9 & 126 & 4.8 \\
\hline Universities & 532 & 54.7 & 2,643 & 72.1 & 1,073 & 49.6 & 5,968 & 68.7 & 401 & 56.4 & 1,807 & 69.1 \\
\hline Trade Unions & 81 & 8.3 & 162 & 4.4 & 189 & 8.7 & 419 & 4.8 & 54 & 7.6 & 116 & 4.4 \\
\hline Cooperatives & 13 & 1.3 & 25 & 0.7 & 13 & 0.6 & 27 & 0.3 & 14 & 2.0 & 37 & 1.4 \\
\hline Companies & 205 & 21.1 & 432 & 11.8 & 579 & 26.8 & 1,313 & 15.1 & 148 & 20.8 & 375 & 14.3 \\
\hline Hospital & 6 & 0.6 & 12 & 0.3 & 35 & 1.6 & 93 & 1.1 & 3 & 0.4 & 9 & 0.3 \\
\hline Others & 58 & 6.0 & 164 & 4.5 & 112 & 5.2 & 388 & 4.5 & 28 & 3.9 & 144 & 5.5 \\
\hline Total & 972 & 100 & 3,666 & 100 & 2,164 & 100 & 8,682 & 100 & 711 & 100 & 2,614 & 100 \\
\hline
\end{tabular}

Source: Authors' own. Data sourced from CNPq (Directory of Research Groups), 2016. Note: there is double counting once one research group could have interacted with agents from other regions too.

Academic collaborations are stronger in Central-West, North and Northeast regions in terms of agents and interactions. It is also important to notice that collaborations with cooperatives are stronger in South and North regions. In its turn, collaborations with hospitals are stronger in Northeast, Southeast and South regions. And finally, collaborations with government agencies are higher in Northeast and Central-West regions than in other regions.

The previous data shows that there are different patterns of collaboration between research groups and society and that the emphasis in interactions with profit seeking companies fostered by 
the Innovation $\mathrm{Law}^{2}$ disregards other agents and collaborations that are especially important in some regions.

Table 11 shows the partner location, whether it is located inside the region (i.e., intra regional partner) or outside the region (i.e., inter regional partner). The inter regional partnerships also embrace universities and research institutions from other countries. We can then note that, research groups from the Southeast region collaborate more with partners from the same region, as this region concentrates the major Brazilian industrial park (Vignandi, Parré, and Guimarães 2016) and has also a higher density of institutions. Collaborations in Northeast, North and Central-West regions are less located within the region. A previous study found that academic excellence of research groups attracts companies from all regions (Caliari and Rapini 2017). Academic collaboration is also less located and partly explains the results from table 10 .

Table 11 - Research groups' partner location, by region, 2016

\begin{tabular}{lrrr}
\hline \hline Region & Intra regional & Inter regional & \% outside region \\
\hline Southeast & 2,692 & 1,417 & 34.5 \\
South & 1,364 & 1,159 & 45.9 \\
Central-West & 416 & 556 & 57.2 \\
North & 299 & 412 & 57.9 \\
Northeast & 843 & 1,321 & 61.0 \\
\hline \hline
\end{tabular}

Source: Authors' own. Data sourced from CNPq (Directory of Research Groups) 2016.

\subsection{Research group analyses}

We presented previously that research groups interactions change according to knowledge field and to geographical regions. However, research groups within the same knowledge field and/or the same geographical region do not interact in the same way. Therefore, we propose here to analyze the top 5 research groups in term of number of partners in each region for 2016.

In Table 12, we present the top 5 research groups, their knowledge fields, their year of establishment, the number of partners with which they interact and the type of partners (we used the same classification presented in the methodology). The data reinforces the previous results that research groups' collaborations are broad, that is, they are not restricted to university-industry relations. Areas from the "Pasteur quadrant" tend to have more cooperation with profit seeking companies - Engineering, Agrarian Science and Exact and Earth Sciences - but there is also an exception. The research group "Trabalho, Tecnologia Social e Desenvolvimento da Amazônia" from Federal University of Para (UFPA) is an example of this, collaborating with cooperatives.

Another interesting observation is that the most interactive research groups from the South and Southeast regions tend to be older than groups from the other regions, as these regions bring together traditional universities and Research Institutes. Inside regions is also possible to identify institutions with more interactive research groups as is the case of Federal University of Bahia (UFBA) in Northeast Region and the Federal University of Para (UFPA) in North Region. It should be highlighted the research groups collaboration with government in its different level - national, state and local - and its potential to solve social problems.

\footnotetext{
2 The Innovation Law (Lei da Inovação) provided legal support and set incentives for the commercialization of the results of scientific and technological research. (Rapini et al. 2019).
} 
Table 12 - Top 5 research group in terms of number of partners, by region, 2016

\begin{tabular}{|c|c|c|c|c|c|c|c|}
\hline & State & Institution & Research Group Name & $\begin{array}{l}\text { Number } \\
\text { of } \\
\text { partners }\end{array}$ & $\begin{array}{l}\text { Year of } \\
\text { Est. }\end{array}$ & $\begin{array}{l}\text { Knowledge } \\
\text { field }\end{array}$ & Partners \\
\hline \multirow{5}{*}{ Z } & PA & UFPA & Trabalho, Tecnologia Social e Desenvolvimento da Amazônia & 13 & 2004 & Social Sciences & Cooperatives \\
\hline & RO & UFRO & Laboratório de Biogeoquímica Ambiental - LABIOGEOQ & 11 & 1994 & Exact and Earth Sciences & Universities \\
\hline & $\mathrm{PA}$ & UFPA & Ecologia & 11 & 2014 & Biological Sciences & Universities \\
\hline & $\mathrm{PA}$ & UFPA & Grupo de Energia, Biomassa e Meio Ambiente & 9 & 1998 & Engineering & Universities, and Government \\
\hline & PA & UFPA & $\begin{array}{l}\text { Valorização Agro-alimentar, Farmacêutica Cosmética de Compostos } \\
\text { Bioativos da Amazônia }\end{array}$ & 9 & 2010 & Agrarian Science & $\begin{array}{l}\text { Profit seeking companies, cooperatives, and } \\
\text { universities }\end{array}$ \\
\hline \multirow{5}{*}{ 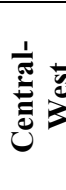 } & $\mathrm{DF}$ & $\mathrm{UCB}$ & Laboratório de Desenvolvimento de Estratégias Terapêuticas & 22 & 2007 & Health Sciences & Universities \\
\hline & $\mathrm{GO}$ & IFG & Núcleo de Pesquisa e Extensão em Tecnologias de Processos Sustentáveis & 22 & 2008 & Exact and Earth Sciences & Universities and Government \\
\hline & $\mathrm{GO}$ & $\mathrm{PUC} / \mathrm{GO}$ & Políticas Educacionais e Gestão Escolar & 20 & 1998 & Human Sciences & Universities, and Government \\
\hline & GO & UFG & Melhoramento de Plantas & 17 & 1985 & Agrarian Science & Profit seeking companies, and cooperatives \\
\hline & DF & UnB & Laboratório de Desenvolvimento de Inovações Terapêuticas & 13 & 2015 & Health Sciences & Universities \\
\hline \multirow{5}{*}{ 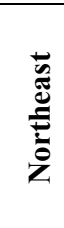 } & $\mathrm{CE}$ & IFCE & Laboratório de Desenvolvimento de Software e Pesquisa & 27 & 2005 & Exact and Earth Sciences & Profit seeking companies \\
\hline & $\mathrm{BA}$ & UFBA & Núcleo de Estudos Conjunturais em Administração & 21 & 2014 & Social Sciences & Universities, and Government \\
\hline & BA & UFBA & Grupo de Pesquisa em História, Filosofia e Ensino de Ciências Biológicas & 20 & 2000 & Human Sciences & Universities \\
\hline & MA & UFMA & Psicoterapias Existenciais e Humanistas & 19 & 2015 & Human Sciences & Universities \\
\hline & PE & UFPE & Grupo de Mecânica dos Fluidos Ambiental & 15 & 1994 & Engineering & $\begin{array}{l}\text { Profit seeking companies, Government, } \\
\text { cooperatives, trade unions, and universities }\end{array}$ \\
\hline \multirow{5}{*}{ 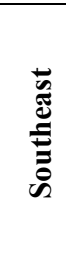 } & RJ & UERJ & TEKTOS - Grupo de Pesquisa em Geotectônica & 43 & 1987 & Exact and Earth Sciences & $\begin{array}{l}\text { Profit seeking companies, Government, and } \\
\text { universities }\end{array}$ \\
\hline & SP & USP & Microbiomas & 34 & 2014 & Agrarian Science & Universities \\
\hline & SP & USP & Gestão da Inovação e Gestão da Inovação Radical & 34 & 2011 & Engineering & $\begin{array}{l}\text { Profit seeking companies, Government, and } \\
\text { cooperatives }\end{array}$ \\
\hline & RJ & UFRJ & Rede de Pesquisas em Sistemas e Arranjos Produtivos e Inovativos Locais & 31 & 1997 & Social Sciences & Universities \\
\hline & $\mathrm{SP}$ & UFSCAR & Grupo de Materiais Cerâmicos Especiais & 29 & 1988 & Exact and Earth Sciences & Profit seeking companies, and Government \\
\hline \multirow{5}{*}{ 吾 } & PR & $\mathrm{PUC} / \mathrm{PR}$ & Planejamento e Projeto em Espaços Urbanos e Regionais & 31 & 2002 & Social Sciences & Universities, and trade unions \\
\hline & $\mathrm{RS}$ & FURG & Bioengenharia de Alimentos & 27 & 2002 & Agrarian Science & $\begin{array}{l}\text { Profit seeking companies, Government, and } \\
\text { universities }\end{array}$ \\
\hline & RS & UFSM & Micotoxinas/Micotoxicoses e Saúde Pública & 26 & 1998 & Agrarian Science & $\begin{array}{l}\text { Profit seeking companies, cooperatives, and } \\
\text { universities }\end{array}$ \\
\hline & $\mathrm{PR}$ & UEM & Grupo de Pesquisa em Stevia & 22 & 1980 & Biological Sciences & Profit seeking companies, and cooperatives \\
\hline & $\mathrm{SC}$ & UFSC & $\begin{array}{l}\text { Grupo de Pesquisa em Cadastro Técnico Multifinalitário e Gestão } \\
\text { Territorial }\end{array}$ & 21 & 1989 & Exact and Earth Sciences & $\begin{array}{l}\text { Profit seeking companies, Government, and } \\
\text { cooperatives }\end{array}$ \\
\hline
\end{tabular}

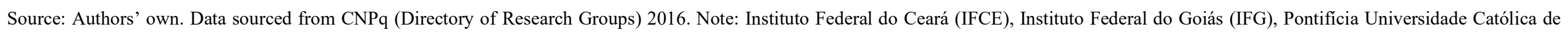

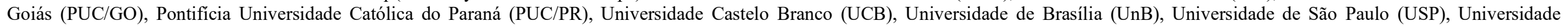

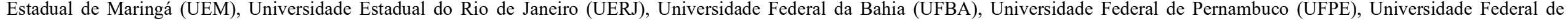

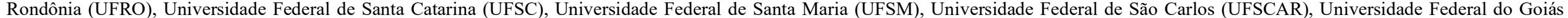
(UFG), Universidade Federal do Maranhão (UFMA), Universidade Federal do Pará (UFPA), Universidade Federal do Rio de Janeiro (UFRJ), Universidade Federal do Rio Grande (FURG). 


\section{Final Remarks}

This paper is a preliminary study focusing on universities' relations that goes beyond the university-industry relationship. Using a database constructed using data from the Directory of Research Groups from CNPq, we demonstrated that universities' collaborations are broader than most studies on the topic in Brazil suppose; especially those influential in the Innovation Studies framework. Therefore, we could present a more comprehensive list of agents with which universities cooperate.

Although the studies that focused on university-industry relations, on the generation of technology and on a narrow concept of innovation provided relevant insights for policy makers, they left aside a set of actors and actions of relative impact for society and for economic and social development. In the same direction, there is a diversity of forms for the transfer of information and knowledge that are generated in universities, not being able to be restricted to the channels encouraged by the ST\&I legal apparatus and managed by universities technology transfer offices.

In fact, according to the new data provided by the last editions of Research Groups CNPq Census, in 2014 and 2016, companies represent nearly half of the agents who interact with universities. It reinforces the perception that a relevant part university-society relationships remain below the radar when the debate focuses on university-industry interactions. Despites being the type of agents with whom universities cooperates the most, the frequency of collaborations between university and industry is proportionally lower, reaching between $18 \%$ and $28 \%$ of all research groups interactions. Hence, in Brazil, while the largest number of agents with whom universities interact was profit seeking companies, the largest number of interactions was performed with other universities.

Arocena et al. (2015) emphasized the importance of policies to identify and to foster social demand by connecting them with high quality available research and transforming research results into effective innovations that contribute to solving social problems. As a consequence, the main role of universities is to contribute to economic and social development, safeguarding a certain level of autonomy. Arocena et al. (2015) still defend this perspective as a response to the contradictory demands placed on universities. The system must combine abilities to meet, in the short term, the needs of society with some degree of autonomy and long-term commitment and should also promote innovation combining it with social and global equality and justice. In this sense, cooperation among universities and other types of societal agents, such as governments and unions and cooperatives, can be an important step forward in the democratization of knowledge and its benefits.

Other relevant identified pattern detected was those regarding regional analyzes. The data converged with the conventional results regarding the concentration of Brazilian scientific and technological infrastructure. For historical reasons, South and Southeast regions concentrate the greater numbers of research groups and university interactions with society. Furthermore, these regions seem to be denser in terms of university-industry relationships. Still, the patterns of intra regional and inter regional interaction indicates that university-society interactions in these regions are more 'endogenous' since research groups in these regions interact more with partners in the same regions than with partners from the North, Northeast and Central-West regions. All those evidence suggest that, while South and Southeast regions have a more endogenous dynamics of university-society interaction, universities in the North, Northeast and Central-West seek partners from other regions to cooperate and share knowledge.

By unveiling some formerly implicit issues about the way universities are inserted in innovation systems, the identified partners are relevant for scholar and policy debate. However, further research is necessary in order to discuss possible causes of these phenomena. As a future research agenda, it will be necessary to expand the analyses for Census 2014, as well as to analyze the geographic proximity between research groups and their partners within Brazilian regions. A special investigation on "Social Sciences" and "Humanities" is also recommended in other to infer 
their role in complying with societal needs. Finally, analyzes on the types of interaction associated with different regions, areas of knowledge or kind of partner may also be useful to public policy.

\section{References}

Albuquerque, Eduardo Motta, Rodrigo Simões, Adriano Baessa, Bernardo Campolina, and Leandro Silva. 2002. "A Distribuição Espacial Da Produção Científica e Tecnológica Brasileira: Uma Descrição de Estatísticas de Produção Local de Patentes e Artigos Científicos." Revista Brasileira de Inovação 1 (2): 225-51.

Arocena, Rodrigo, Bo Göransson, and Judith Sutz. 2015. "Knowledge Policies and Universities in Developing Countries: Inclusive Development and the 'Developmental University."' Technology in Society 41: 10-20.

Arocena, Rodrigo, and Judith Sutz. 2005. "Latin American Universities: From an Original Revolution to an Uncertain Transition." Higher Education 50: 573-92.

. 2011. "Uruguay: Higher Education, National System of Innovation, and Economic Development in a Small Peripheral Country." In Universities in Transition: The Changing Role and Challenges for Academic Institutions, edited by Bo Göransson and Claes Brundenius, 77-99. New York: Springer.

—. 2013. "Innovación y Democratización Del Conocimiento Como Contribución Al Desarrollo Inclusivo." In Sistemas de Innovación Para Un Desarrollo Inclusivo: La Experiencia Latinoamericana., edited by Gabriela Dutrénit and Judith Sutz, 19-34. Mexico City: Foro Consultivo Científico y Tecnológico.

Audretsch, David B. 2014. "From the Entrepreneurial University to the University for the Entrepreneurial Society." Journal of Technology Transfer 39 (3): 313-21.

Bercovitz, Janet, and Maryann Feldmann. 2006. "Entpreprenerial Universities and Technology Transfer: A Conceptual Framework for Understanding Knowledge-Based Economic Development." Journal of Technology Transfer 31: 175-88.

Britto, Jorge, Marco Antônio Vargas, Carlos Augusto Grabois Gadelha, and Laís Silveira Costa. 2012. "Health-Related Scientifi c and Technological Capabilities and University-Industry Research Collaboration." Revista de Saúde Pública 46: 41-50.

Brundenius, Claes, Bengt-Åke Lundvall, and Judith Sutz. 2008. "Developmental University Systems: Empirical, Analytical and Normative Perspectives." In Proceeding of the IV Globelics Conference. Mexico City.

Caliari, Thiago, and Tulio Chiarini. 2018. "Análisis de Los Grupos de Investigación de Las Áreas Científicas Con Mayor Aplicabilidad Productiva En El Brasil: Competencias e Interacciones Con Las Empresas.” Apuntes 82: 71-98.

Caliari, Thiago, and Marcia Siqueira Rapini. 2017. "Diferenciais Da DistâNcia Geográfica Na Interação Universidade-Empresa No Brasil: Um Foco Sobre as Características Dos Agentes e Das Interações.” Nova Economia 27 (1): 271-302.

Cassiolato, Jose, and Helena Lastres. 2008. "Discussing Innovation and Development: Converging Points between the Latin American School and the Innovation Systems Perspective." 2008-02. Globelics Working Paper Series.

Chiarini, T., V.P. Oliveira, F.C. Do Couto, and S. Neto. 2014. "Spatial Distribution of Scientific Activities: An Exploratory Analysis of Brazil, 2000-10." Science and Public Policy 41 (5): 625-40.

Closs, Lisiane, Gabriela Ferreira, Cláudio Sampaio, and Marcelo Perin. 2012. "Factors That Influence the University-Industry Technology Transfer Process: The Case of PUCRS." Revista de Administração ContemporâNea 16 (1): 61-78.

Cohen, Wesley M., Richard R. Nelson, and John P. Walsh. 2002. "Links and Impacts: The Influence of Public Research on Industrial R\&D.” Management Science 48 (1): 1-23.

Conceição Fátima Silva, and Wilson Suzigan. 2018. "Sistema Setorial de Inovação Da Metalurgia Básica." In Estudos de Caso Da Interação Universidade-Empresa No Brasil, edited by Renato 
Garcia, Marcia Siqueira Rapini, and Silvio Cario, 159-201. Belo Horizonte: FACE/UFMG.

Coutinho, Luciano G. 2005. "Regimes Macroeconômicos e Estratégias de Negócios: Uma Política Industrial Alternativa Para o Brasil No Século XXI.” In Conhecimento, Sistemas de Inovação e Desenvolvimento, edited by Helena Lastres, Jose Cassiolato, and Ana Arroio, 429-48. Rio de Janeiro: UFRJ.

Dagnino, Renato. 2015. “Como é a Universidade de Que o Brasil Precisa?” Avaliação 20 (2): 293333.

Dalmarco, Gustavo, Willem Hulsink, and Guilherme V. Blois. 2018. "Creating Entrepreneurial Universities in an Emerging Economy: Evidence from Brazil." Technological Forecasting \& Social Change.

Dias, Fernando S. R., Silvio A. F. Cario, Daniela C. Lemos, Pablo F. Bittencourt, and Paola Azevedo. 2018. "Interação Universidade e Empresa Para Desenvolvimento Inovativo Em Santa Catarina: Estudo Sobre a Parceira UFSC e Embraco.” In Estudos de Caso Da Interação Universidade-Empresa No Brasil, edited by Renato Garcia, Marcia Siqueira Rapini, and Silvio Cario, 204-29. Belo Horizonte: FACE/UFMG.

Diniz, Clélio Campolina, and Danilo Jorge Vieira. 2015. "Ensino Superior e Desigualdades Regionais: Notas Sobre a Experiência Recente Do Brasil." Revista Paranaense de Desenvolvimento 36 (129): 99-115.

Dutrénit, Gabriela, and Valéria Arza. 2010. "Channels and Benefits of Interactions between Public Research Organisations and Industry: Comparing Four Latin American Countries." Science \& Public Policy 37 (7): 541-53.

Dutrénit, Gabriela, and Jorge Núñez. 2017. Vinculación Universidad-Sector Productivo Para Fortalecer Los Sistemas Nacionales de Innovación: Experiencias de Cuba, México y Costa Rica. La Habana (Cuba): Editorial UH.

Etzkowitz, Henry. 1983. "Entrepreneurial Scientists and Entrepreneurial Universities in American Academic Science." Minerva 21 (2/3): 198-233.

Fernandes, A C, B Campello de Souza, A Stamford Silva, W Suzigan, C V Chaves, and E Albuquerque. 2010. "Academy-industry Links in Brazil: Evidence about Channels and Benefits for Firms and Researchers." Science \& Public Policy 37 (7): 485-98.

Fernandes, Ana Cristina, and João Policarpo R. Lima. 2018. "Labirintos Da Interação Universidade-Empresa: Estudos de Caso Dos Setores Elétrico e Sucroalcooleiro Em Pernambuco." In Estudos de Caso Da Interação Universidade Empresa No Brasil, edited by Renato Garcia, Marcia Siqueira Rapini, and Silvio Cário, 60-78. Belo Horizonte: FACE/UFMG.

Ferreira, Marta Lucia Azevedo, and Ricardo Rezende Ramos. 2015. "Making University-Industry Technological Partnerships Work: A Case Study in the Brazilian Oil Innovation System." Journal of Technology Management \& Innovation 10 (1): 173-87.

Freeman, Chris. 1987. Technology Policy and Economic Performance: Lessons from Japan. London: Pinter Publishers. 514.

1994. "The Economics of Technical Change." Cambridge Journal of Economics 18: 463. 1995. "The 'National System of Innovation' in Historical Perspective." Cambridge Journal of Economics 19: 5-24.

Garcia, Renato, Veneziano Araújo, Suelene Mascarini, Emerson Gomes Santos, and Ariana Ribeiro Costa. 2014. "Interações Universidade-Empresa e a Influência Das Características Dos Grupos de Pesquisa Acadêmicos." Revista de Economia ContemporâNea 18 (1): 99-120.

Gielfi, Giovanna Guimarães, André Tosi Furtado, André Sica Campos, and Robert J. W. Tijssen. 2017. "University-Industry Research Collaboration in the Brazilian Oil Industry: The Case of Petrobras." Revista Brasileira de Inovação 16 (2): 325-50.

Klevorick, Alvin K., Richard C. Levin, Richard Nelson, and Sidney Winter. 1995. "On the Sources and Significance of Inter-Industry Differences in Technological Opportunities." Research Policy 24 (2): 185-205. 
Klofsten, Magnus, Alain Fayolle, Maribel Guerrero, Sarfraz Mian, David Urbano, and Mike Wright. 2018. "The Entrepreneurial University as Driver for Economic Growth and Social Change - Key Strategic Challenges." Technological Forecasting \& Social Change.

Lundvall, Bengt-Åke. 1992. National Innovation Systems: Towards a Theory of Innovation and Interactive Learning. Edited by Bengt-Åke Lundvall. London: Pinter Publishers.

. 2002. "The University in the Learning Economy." 6. DRUID Working Paper Series.

. 2007. "Higher Education, Innovation and Economic Development." In Proceeding of the World Bank's Regional Bank Conference on Development Economics. Beijing.

Mello, José Manoel Carvalho, Claudia Fuentes, and Donato Iacobucci. 2016. "Introduction to the Special Issue: Universities as Interactive Partners." Science \& Public Policy 43: 1-29.

Meyer-Krahmer, Frieder, and Ulrich Schmoch. 1998. "Science-Based Technologies: Universityindustry Interactions in Four Fields." Research Policy 27 (8): 835-51.

Nelson, Richard. 1993. National Innovation Systems: A Comparative Analysis. Edited by Oxford University Press. New York.

Nelson, Richard, and Nathan Rosenberg. 1993. "Technical Innovation and National Systems.” In National Innovation Systems: A Comparative Analysis, edited by Richard Nelson. New York: Oxford University Press.

Núñez, Jorge, and Ariamnis Alcazar Quiñones. 2016. Universidad y Desarrollo Local: Contribuciones Latinoamericanas. Mexico City: Felix Varela.

Oliveira, Vanessa Parreiras, Tulio Chiarini, Marcia Siqueira Rapini, and Pablo Felipe Bittencourt. 2018. "Análise Exploratória Da Produção de Conhecimento Na Região Sul Do Brasil e as Relações Universidade-Empresa." Revista de Economia (UFPR) 39 (68).

Paranhos, Julia, and Fernanda Steiner Perin. 2018. "Relacionamento Universidade-Empresa No Setor Farmacêutico: Duas Pesquisas Comparadas." In Estudos de Caso Da Interação Universidade Empresa No Brasil, edited by Renato Garcia, Márcia Siqueira Rapini, and Silvio Antônio Ferraz Cário, 79-104. Belo Horizonte: FACE/UFMG.

Rapini, Marcia Siqueira, Tulio Chiarini, Pablo Bittencourt, and Thiago Caliari. 2019. "The Intensity of Private Funding and the Results of University? Firm Interactions: The Case of Brazil." Innovation \& Management Review.

Reynolds, Elisabeth B., and Fernanda Negri. 2019. "Universities as Engines of Innovation. The Context for Tech Transfer in Case Studies from Brazil and the U.S." In Innovation in Brazil Advancing Development in the 21st Century, edited by Elisabeth B. Reynolds, Ben Ross Schneider, and Ezequiel Zylberberg. New York: Routledge.

Ruffoni, Janaína, and Andréia Cunha da Rosa. 2018. "Desempenho Inovativo e Capacidade Absortiva de Firmas Que Interagem Com Universidades: Uma Análise Para a Área Da Engenharias Do Rio Grande Do Sul." In Estudos de Caso Da Interação UniversidadeEmpresa No Brasil, edited by Renato Garcia, Marcia Siqueira Rapini, and Silvio Cario, 386416. Belo Horizonte: FACE/UFMG.

Santos, Ulisses, and Thiago Caliari. 2012. "Distribuição Espacial Das Estruturas de Apoio Às Atividades Tecnológicas No Brasil: Uma Análise Multivariada Para as Cinquenta Maiores Microrregiões Do País." Economia 13 (3b): 759-83.

Sidone, Otávio José Guerci, Eduardo Amaral Haddad, and Jesús Pascual Mena-Chalco. 2016. “A Ciência Nas Regiões Brasileiras: Evolução Da Produção e Das Redes de Colaboração Científica." TransInformação 28 (1): 15-31.

Silveira, Zuleide Simas, and Lucídio Bianchetti. 2016. "Universidade Moderna: Dos Interesses Do Estado-Nação Às Conveniências Do Mercado.” Revista Brasileira de Educação 21 (64).

Suzigan, Wilson, Eduardo Albuquerque, Renato Garcia, and Marcia Siqueira Rapini. 2009. "University and Industry Linkages in Brazil: Some Preliminary and Descriptive Results." Seoul Journal of Economics 22 (4): 591-611.

Suzigan, Wilson, and Eduardo Motta Albuquerque. 2011. "The Underestimated Role of Universities for the Brazilian System of Innovation." Brazilian Journal of Political Economy 31 (1): 3-30. 
Suzigan, Wilson, Eduardo Motta Albuquerque, and Silvio Cario. 2011. Em Busca Da Inovação: Interação Universidade-Empresa No Brasil. Edited by Wilson Suzigan, Eduardo Motta Albuquerque, and Silvio Cario. Belo Horizonte: Autêntica Editora.

Tatsch, Ana Lúcia, Janaina Ruffoni, and Marisa Reis A. Botellho. 2016. "Sistema de Innovación de La Salud: Redes En Rio Grande Do Sul/Brasil.” América Latina Hoy 73: 87-119.

Vignandi, Rafaella Stradiotto, José Luiz Parré, and Paulo Guimarães. 2016. "Measures of Industry Agglomeration in Brazil: A Study Addressing Neighboring Effects." Análise Econômica 34 (65): 301-32. 